\title{
Acetylcholine Triggers L-Glutamate Exocytosis via Nicotinic Receptors and Inhibits Melatonin Synthesis in Rat Pinealocytes
}

\author{
Hiroshi Yamada, ${ }^{1}$ Akihiko Ogura, ${ }^{2}$ Shinichi Koizumi, ${ }^{3}$ Akihito Yamaguchi, ${ }^{1}$ and Yoshinori Moriyama ${ }^{1}$ \\ ${ }^{1}$ Department of Cell Membrane Biology, Institute of Scientific and Industrial Research (ISIR), Osaka University, Ibaraki, \\ Osaka 567, Japan, 2Department of Biology, Osaka University Graduate School of Science, Toyonaka, Osaka 560, Japan, \\ and ${ }^{3}$ Novartis Pharma K. K., Takarazuka 665, Japan
}

\begin{abstract}
Rat pinealocytes, melatonin-secreting endocrine cells, contain peripheral glutaminergic systems. L-Glutamate is a negative regulator of melatonin synthesis through a metabotropic receptor-mediated inhibitory cAMP cascade. Previously, we reported that depolarization of pinealocytes by externally added $\mathrm{KCl}$ and activation of L-type $\mathrm{Ca}^{2+}$ channels resulted in secretion of L-glutamate by microvesicle exocytosis. What is unknown is how and what kinds of stimuli trigger glutamate exocytosis under physiological conditions. Here, we report that the nicotinic acetylcholine receptor can trigger glutamate exocytosis from cultured rat pinealocytes. Moreover, acetylcholine or nicotine inhibited norepinephrine-dependent serotonin $\mathrm{N}$-acetyltransferase activity, which results in decreased mela-
\end{abstract}

tonin synthesis. These activities were blocked by (2S,3S,4S)-2methyl-2-(carboxycyclopropyl)glycine, an antagonist of the metabotropic glutamate receptor. These results suggest that cholinergic stimulation initiates the glutaminergic signaling cascade in pineal glands and that parasympathetic neurons innervating the gland exert negative control over melatonin synthesis by way of the glutaminergic systems.

Key words: microvesicle (synaptic-like microvesicle); acetylcholine; nicotinic acetylcholine receptor (nAchR); exocytosis; glutamate; pinealocyte; pineal gland; L-type $\mathrm{Ca}^{2+}$ channel; serotonin $\mathrm{N}$-acetyltransferase; parasympathetic neuron; melatonin synthesis
The mammalian pineal gland is a photoneuroendocrine transducer that rhythmically synthesizes and secretes melatonin at night in response to photoperiodic stimuli and signals from endogenous circadian oscillators (for review, see Axelrod, 1974; Klein, 1985; Reiter, 1991). In the rat, this process is controlled by sympathetic neurons projecting into the glands. These neurons secrete norepinephrine (NE), which binds to adrenergic $\alpha 1$ and $\beta 1$ receptors. Stimulation of $\beta 1$ receptors causes increased intracellular cAMP leading to transcriptional activation of the serotonin $\mathrm{N}$-acetyltransferase (NAT) gene, which results in increased melatonin output (for review, see Foulkes et al., 1997). Furthermore, stimulation of $\alpha 1$ receptors potentiates the activation effect of $\beta 1$ receptors by increasing intracellular $\mathrm{Ca}^{2+}$ concentration $\left(\left[\mathrm{Ca}^{2+}\right] \mathrm{i}\right)$ by release from intracellular stores (Klein, 1985). On the basis of this information, the role of sympathetic innervation as a positive regulatory mechanism for melatonin synthesis has been firmly established.

In addition to adrenergic pathways, there is evidence for other types of neuronal control of synthesis and secretion of melatonin (Reiter, 1991; Korf et al., 1996). For example, morphological and immunohistochemical evidence suggests parasympathetic innervation of mammalian pineal glands (for review, see Moller, 1992; Laitinen et al., 1995). These neurons may originate from the

\footnotetext{
Received Feb. 27, 1998; revised April 16, 1998; accepted April 20, 1998.

H.Y. is supported by a research fellowship from the Japan Society for Promotion of Science. This study was supported in part by grants from the Japanese Ministry of Education, Science and Culture. We thank Professor H.-W. Korf for valuable discussion, Professor R. K. Nakamoto (University of Virginia) for critical reading of this manuscript, and Professor S. Kozaki for providing BoNT/E.

Correspondence should be addressed to Dr. Y. Moriyama, Department of Cell Membrane Biology, Institute of Scientific and Industrial Research (ISIR), Osaka University, Ibaraki, Osaka 567, Japan.

Copyright (C) 1998 Society for Neuroscience $\quad 0270-6474 / 98 / 184946-07 \$ 05.00 / 0$
}

pterygopalatine ganglion and use acetylcholine as a neurotransmitter (Moller, 1992; Laitinen et al., 1995) to activate nicotinic and muscarinic acetylcholine receptors that have been identified in the pineal gland (Wada et al., 1989; Pujito et al., 1991a; Reuss et al., 1992; Stankov et al., 1993). After binding of acetylcholine to receptors, NE-dependent melatonin synthesis is markedly inhibited, which suggests a negative regulatory role of parasympathetic innervation (Pujito et al., 1991b; Stankov et al., 1993; Drijfhout et al., 1996). The mechanism by which acetylcholine inhibits melatonin synthesis is not known, and the question of whether muscarinic or nicotinic receptors participate in this inhibitory processes is still controversial.

Peripheral glutaminergic systems recently identified in pineal glands are also involved in negative regulation of melatonin synthesis (for review, see Moriyama et al., 1996). Pinealocytes secrete L-glutamate through microvesicle-mediated exocytosis (Yamada et al., 1996a) to affect inhibition of NE-dependent melatonin synthesis. In this case, activation of metabotropic type 3 glutamate receptors (mGluR3) initiates an inhibiting cAMP cascade and results in decreased NAT activity (Yamada et al., 1998). Under in vitro experimental conditions, glutamate exocytosis can be triggered by the addition of external $\mathrm{KCl}$, which depolarizes the cell membrane and activates L-type $\mathrm{Ca}^{2+}$ channels (Yamada et al., 1996a,b; Yatsushiro et al., 1997). The in vivo stimuli that initiate glutamate exocytosis remain to be understood.

Recently, Korf and colleagues (Letz et al., 1997) found that acetylcholine will depolarize pinealocyte membranes by activation of nicotinic acetylcholine receptor (nAchR). Combining this observation with our recent findings (Yamada et al., 1996b), we hypothesized that acetylcholine- and glutamate-evoked signaling cascades overlap. Here, we report that in rat pineal glands ace- 
tylcholine triggers glutamate exocytosis via nAchR and inhibits NE-dependent melatonin synthesis through an inhibitory cAMP cascade. Our results suggest that parasympathetic neurons negatively control melatonin synthesis by way of endogenous glutaminergic systems in pineal glands.

\section{MATERIALS AND METHODS}

Cell culture. Cells were isolated from the pineal glands of Wistar rats at 7 weeks postnatal and were cultured by published procedures (Yamada et al., 1996a,b). Briefly, pineal glands were dissected into small pieces, treated with a $0.1 \%$ collagenase solution (Life Technologies, Gaithersburg, MD) at $37^{\circ} \mathrm{C}$ for 30 min with gentle shaking, and then washed with PBS. After centrifugation at $180 \times g$ for $2 \mathrm{~min}$, the pieces were treated with a $0.025 \%$ trypsin solution (Life Technologies) at $37^{\circ} \mathrm{C}$ for $20 \mathrm{~min}$ and then centrifuged at $180 \times g$ for $5 \mathrm{~min}$. The dispersed cells were washed three times with DMEM supplemented with $6 \%$ fetal calf serum, $55 \mathrm{mg} / \mathrm{ml}$ sodium pyruvate, $6 \mathrm{mg} / \mathrm{ml}$ glucose, $0.1 \mathrm{mg} / \mathrm{ml}$ streptomycin, 100 $\mathrm{U} / \mathrm{ml}$ penicillin $\mathrm{G}$, and $0.25 \mathrm{mg} / \mathrm{l}$ fungizone and placed in a culture dish (35-mm-diameter) coated with type I collagen (Corning, Corning, NY) at $1.3 \times 10^{6}$ cells/dish. Cells were cultured in the above medium at $37^{\circ} \mathrm{C}$ under $10 \% \mathrm{CO}_{2}$. More than $99.5 \%$ cells that became attached to the dish were pinealocytes, as shown by the positive reactivity toward antimelatonin and anti-synaptophysin antibodies (Yamada et al., 1996a). The viability of the cells did not change after treatment with the various reagents used in this study, as judged by staining with $0.3 \%$ Trypan blue and vital staining with acridine orange.

Assay of glutamate exocytosis. Pinealocytes $\left(1.3 \times 10^{6} \mathrm{cells} / \mathrm{dish}\right)$ were preincubated at $28^{\circ} \mathrm{C}$ for $30 \mathrm{~min}$ and then washed with Ringer's solution composed of $128 \mathrm{mM} \mathrm{NaCl}, 1.9 \mathrm{~mm} \mathrm{KCl}, 1.2 \mathrm{mM} \mathrm{KH}_{2} \mathrm{PO}_{4}, 2.4 \mathrm{~mm}$ $\mathrm{CaCl}_{2}, 1.3 \mathrm{~mm} \mathrm{MgSO}$, $26 \mathrm{~mm} \mathrm{NaHCO}_{3}, 10 \mathrm{~mm}$ glucose, and $10 \mathrm{~mm}$ HEPES, pH 7.4, or - $\mathrm{Ca}^{2+}$-Ringer's solution composed of $128 \mathrm{mM} \mathrm{NaCl}$, $1.9 \mathrm{~mm} \mathrm{KCl}, 1.2 \mathrm{~mm} \mathrm{KH}_{2} \mathrm{PO}_{4}, 0.2 \mathrm{~mm} \mathrm{CaCl}_{2}, 1 \mathrm{~mm}$ EGTA, $3.8 \mathrm{~mm}$ $\mathrm{MgSO}_{4}, 26 \mathrm{~mm} \mathrm{NaHCO}, 10 \mathrm{~mm}$ glucose, and $10 \mathrm{~mm}$ HEPES, pH 7.4. After cells were incubated in $2 \mathrm{ml}$ of the above medium at $28^{\circ} \mathrm{C}$, exocytosis was stimulated by the addition of either $50 \mathrm{~mm} \mathrm{KCl}$ (Yamada et al., 1996a) or $0.2 \mathrm{~mm}$ acetylcholine. When necessary, various $\mathrm{Ca}^{2+}$ channel agonists or antagonists were included in the incubation medium. Finally, $10 \mu \mathrm{l}$ aliquots were taken at intervals, and the amount of extracellular glutamate was determined by HPLC with precolumn o-phthalaldehyde (OPA) derivatization, separation by a reverse-phase RESOLVE C18 column $(3.9 \times 150 \mathrm{~mm}$; Waters Associates, Milford, MA), and fluorescence detection (Godel et al., 1984).

Treatment of pinealocytes with botulinum neurotoxin type $E$ (BoNT/E). Pinealocytes were treated with BoNT/E by a procedure similar to that described previously (Yamada et al., 1996a; Yatsushiro et al., 1997). In brief, pinealocytes $\left(1.3 \times 10^{6}\right.$ cells/dish $)$ were incubated at $37^{\circ} \mathrm{C}$ for $24 \mathrm{hr}$ in a low ionic strength buffer consisting of $5 \mathrm{~mm} \mathrm{NaCl}, 4.8 \mathrm{~mm} \mathrm{KCl}, 2.2$ $\mathrm{mm} \mathrm{CaCl} 2,1.2 \mathrm{~mm} \mathrm{MgSO}_{4}, 20 \mathrm{~mm}$ HEPES-NaOH, pH 7.4, $5.6 \mathrm{~mm}$ glucose, $220 \mathrm{~mm}$ sucrose, and $0.5 \%$ bovine serum albumin in the presence or absence of either $15 \mathrm{~nm}$ or $50 \mathrm{~nm}$ BoNT/E. After treatment, cells were washed with fresh culture medium and incubated an additional $12 \mathrm{hr}$ at $37^{\circ} \mathrm{C}$. Finally, acetylcholine-evoked glutamate release was measured as described above.

Measurement of intracellular $\left[\mathrm{Ca}^{2+}\right]$. Pinealocytes were cultured for $3 \mathrm{~d}$ on a thin glass coverslip precoated with type I collagen (thickness 0.12 $\mathrm{mm}$ and diameter $40 \mathrm{~mm} ; 8.0 \times 10^{5}$ cells/coverslip) in the medium as described (Ogura et al., 1990). After changing the culture medium to DMEM, cells were treated with $5 \mu \mathrm{M}$ fura-2 AM (Dojin Company) for $50 \mathrm{~min}$ at $37^{\circ} \mathrm{C}$ in DMEM and then washed twice with the same medium. The cells were perfused with warmed Ringer's solution or $-\mathrm{Ca}^{2+}$. Ringer's solution, and images were continuously taken at $28^{\circ} \mathrm{C}$ with a silicon-intensified target camera (Hamamatsu Photonics C-2400-08) at a sampling rate of $30 \mathrm{sec}^{-1}$, and recorded on videotape. The output of the camera or of the videotape recorder (Sony V0-5850) was fed into a Hamamatsu DVS-3000 image analyzer. The software enabled subtraction of background fluorescence, pixel-to-pixel division of F340 × F360 images, fitting of the $\mathrm{F} 340 / \mathrm{F} 360$ ratios to a $\left[\mathrm{Ca}^{2+}\right]$ calibration curve prepared separately, and digital averaging of $\left[\mathrm{Ca}^{2+}\right]$ in multiple cells.

Other procedures. Melatonin was measured by HPLC with an IRICA RP-18T column and an amperometric detector (E-558) as described by Sagara et al. (1988). NAT activity was measured as described by Thomas et al. (1990). Immunoblotting and PAGE were performed as described previously (Moriyama and Yamamoto, 1995a,b). cAMP concentrations were measured with an Amersham cAMP enzyme-immunoassay kit (Amersham, Arlington Heights, IL), and protein was measured by the Bio-Rad protein assay kit (Bio-Rad, Richmond, CA).

Materials. Antagonists and agonists of acetylcholine receptor were from Sigma (St. Louis, MO). 1,4-Dihydro-2,6-dimethyl-5-nitro4[trifluoromethyl-phenyl]-3-pyridinecarboxylic acid methylester (BAY K8644) was obtained from Research Biochemicals International (Natick, MA). (2S,3S,4S)-2-methyl-2-(carboxycyclopropyl)glycine (MCCG), a specific antagonist for class II mGluRs (Sekiyama et al., 1996), was obtained from Tocris Neuramin. BoNT/E was kindly provided by Professor S. Kozaki (Osaka Prefecture University). Monoclonal antibodies against synaptic vesicle-associated protein 25 (SNAP25) (BR05) and polyclonal antibodies against synaptobrevin 2 (VAMP2) were obtained from Wako Chemicals (Osaka, Japan). Other chemicals were of the highest grade commercially available.

\section{RESULTS}

\section{Acetylcholine-evoked L-glutamate exocytosis}

Our previous studies indicated that L-glutamate in microvesicles was exocytized from pinealocytes after depolarization of the cell membrane evoked by the addition of $50 \mathrm{~mm}$ or more $\mathrm{KCl}$
Figure 1. Characterization of acetylcholine-evoked L-glutamate secretion from cultured pinealocytes. $A$, Glutamate concentration in the medium at the indicated times after the addition of $200 \mu \mathrm{M}$ acetylcholine was monitored as described in Materials and Methods. Cells were incubated at $28^{\circ} \mathrm{C}(\bullet), 22^{\circ} \mathrm{C}$ $(\boldsymbol{\Lambda})$, or $18^{\circ} \mathrm{C}(\bigcirc)$. Results were expressed as mean \pm SEM (4 independent experiments). $B$, Lineweaver-Burk plot of acetylcholine dose-dependence after $10 \mathrm{~min}$. The derived $K_{\mathrm{m}}$ and $V_{\max }$ values were $63 \mu \mathrm{M}$ and $0.22 \mathrm{nmol} / \mathrm{min}$ per $10^{6}$ cells, respectively.
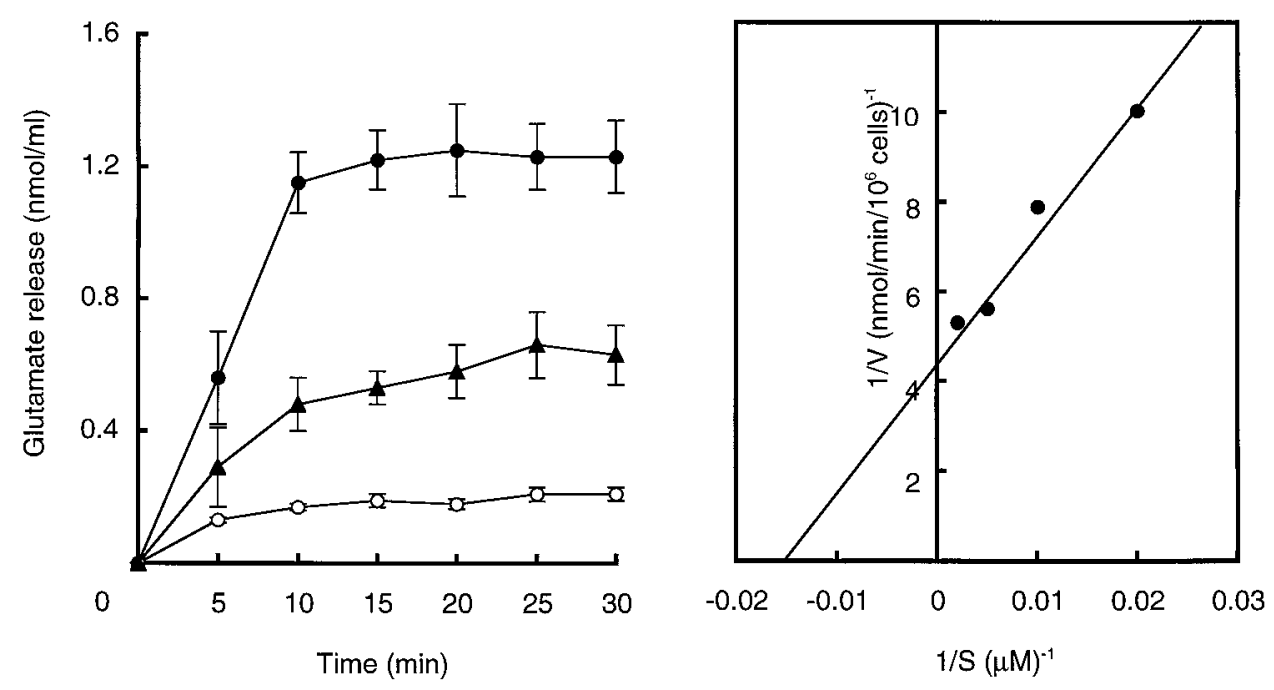
Glutamate release (\% of control)

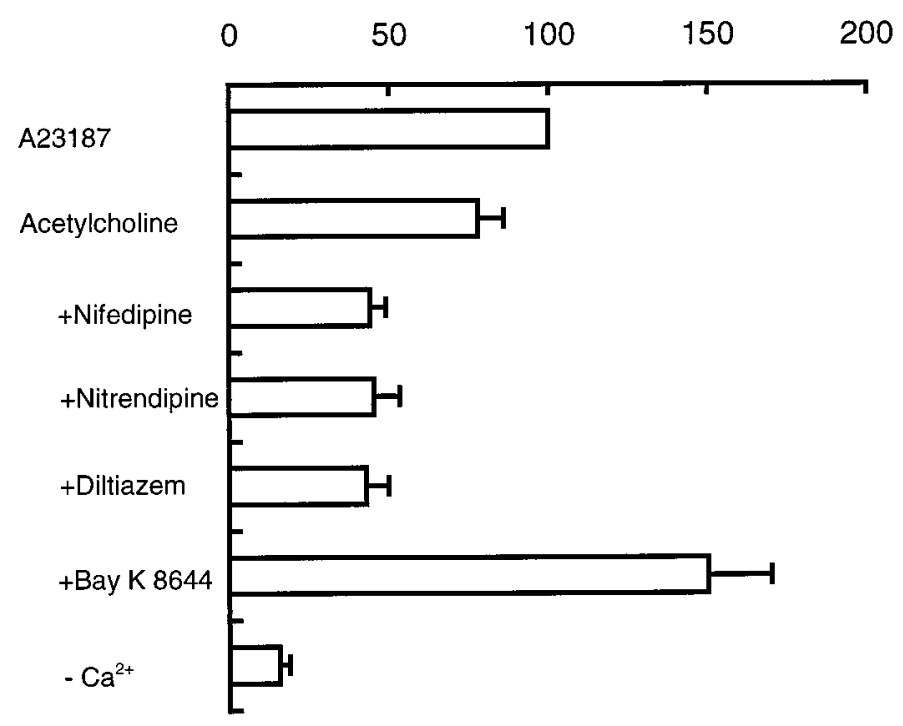

Figure 2. Involvement of L-type $\mathrm{Ca}^{2+}$ channels in acetylcholine-evoked glutamate secretion. Cells were treated with the indicated L-type $\mathrm{Ca}^{2+}$ channel antagonists $(20 \mu \mathrm{M}$ each) or BAY K8644 $(1 \mu \mathrm{M})$ for $10 \mathrm{~min}$ and washed once with medium. Cells were then stimulated with $200 \mu \mathrm{M}$ acetylcholine for $10 \mathrm{~min}$, and aliquots of medium were taken for determination of glutamate. The results were expressed as relative values \pm SEM (three independent experiments). The amount of glutamate released on addition of $5 \mu \mathrm{M} \mathrm{Ca}^{2+}$ ionophore A23187 (2.2 nmol glutamate/ $10^{6}$ cells) was taken as $100 \%$, and glutamate secretion in the absence of $\mathrm{Ca}^{2+}$ in the medium $\left(-\mathrm{Ca}^{2+}\right.$-Ringer's solution) is shown to indicate background levels (control levels).

(Yamada et al., 1996a). A rise of intracellular $\left[\mathrm{Ca}^{2+}\right]$ via voltagegated L-type $\mathrm{Ca}^{2+}$ channels is responsible for the secretion process (Yamada et al., 1996b). We report here that acetylcholine can also stimulate appreciable amounts of L-glutamate exocytosis (Fig. 1A). The rate of secretion increases in a saturable manner with increasing concentrations of acetylcholine with a calculated $\mathrm{Km}$ value of $63 \mu \mathrm{M}$ (Fig. 1B). Approximately $1.8 \mathrm{nmol}$ of glutamate was released from $10^{6}$ cells after a 10 min incubation with acetylcholine. Acetylcholine-induced glutamate secretion was dependent on temperature: release was observed at $28^{\circ} \mathrm{C}$, decreased gradually with decreasing temperature, and disappeared below $18^{\circ} \mathrm{C}$ (Fig. $1 \mathrm{~A}$ ). Above $32^{\circ} \mathrm{C}$, pinealocytes became sensitive to mechanical stimulation such as medium replacement and readily released glutamate even in the absence of acetylcholine. At $28^{\circ} \mathrm{C}$, essentially no glutamate was released by mechanical stimulation such as medium replacement. Because of this behavior, subsequent experiments were performed at $28^{\circ} \mathrm{C}$ to ensure quantitative secretion measurements. Involvement of either eserine or neostigmine at $50 \mu \mathrm{M}$, inhibitors of acetylcholine esterase, did not affect the acetylcholine-induced glutamate secretion. This excludes a possibility that the enzyme perturbed the acetylcholine effect under the assay condition. After a round of glutamate release, successive additions of acetylcholine did not induce further secretion. The ability to secrete glutamate gradually returned during a $12 \mathrm{hr}$ period (data not shown). These properties were consistent with those of $\mathrm{KCl}$-evoked glutamate secretion (Yamada et al., 1996a), suggesting that acetylcholine-evoked glutamate secretion is also mediated through microvesicle exocytosis.

We conducted two lines of experiments to show that
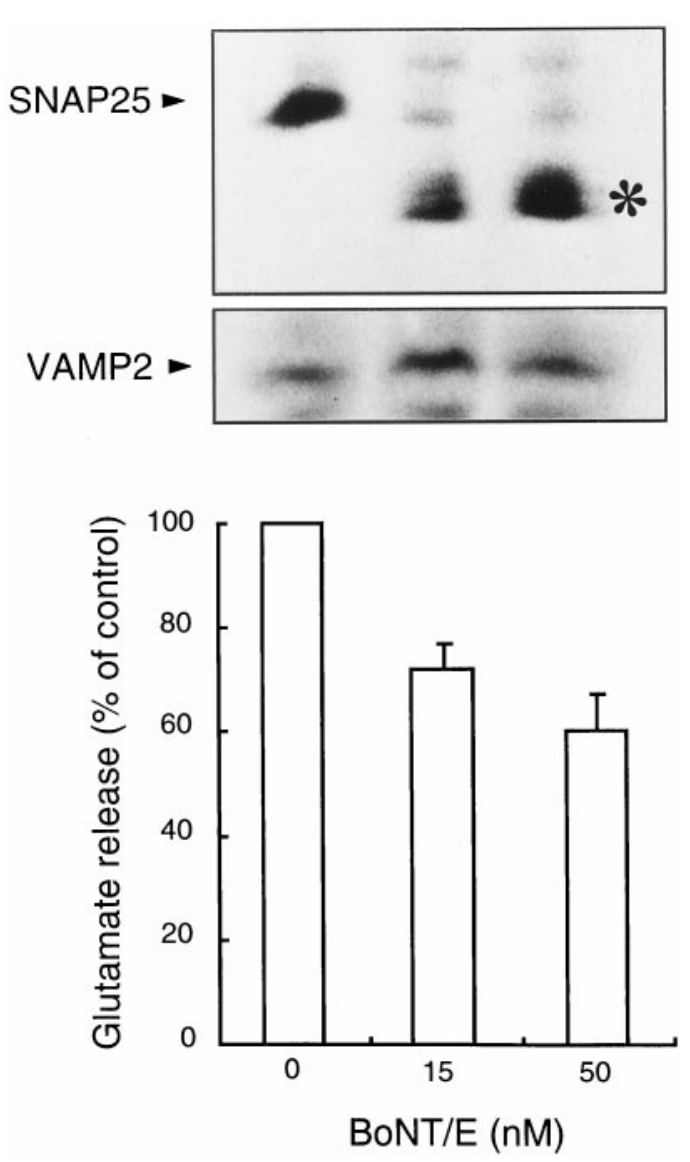

Figure 3. Effects of BoNT/E on acetylcholine-evoked glutamate secretion. Cells were treated with $\mathrm{BoNT} / \mathrm{E}$ at the indicated concentrations as described in Materials and Methods. After treatment, acetylcholineevoked glutamate release for $10 \mathrm{~min}$ was determined. Results in the bottom panel are expressed as relative values \pm SEM (4 independent experiments); $100 \%$ value is $1.8 \mathrm{nmol}$ glutamate $/ 10^{6}$ cells. In the top panel, the same cells were washed with PBS containing DNase and dissolved in sample buffer containing $10 \%$ SDS and $\beta$-mercaptoethanol. After dissociation of the proteins, samples were separated over a $13 \%$ polyacrylamide gel in the presence of SDS and analyzed by immunoblotting using antibodies against SNAP-25 and VAMP2 as indicated. The position of cleaved SNAP-25 is indicated by *.

acetylcholine-evoked exocytosis involved microvesicles. First, we assessed the role of $\mathrm{Ca}^{2+}$ (Fig. 2). Removal of $\mathrm{Ca}^{2+}$ from the medium reduced acetylcholine-evoked glutamate secretion by $80 \%$. Diltiazem, nifedipine, and nitrendipine, L-type $\mathrm{Ca}^{2+}$ channel blockers (Tsien et al., 1988), inhibited $\sim 50 \%$ of acetylcholineevoked glutamate release, whereas BAY K8644, an L-type $\mathrm{Ca}^{2+}$ channel agonist (Bellemann and Frankowiak, 1985; Nowycky et al., 1985), stimulated secretion twofold over the acetylcholine response. These results strongly suggest the involvement of L-type $\mathrm{Ca}^{2+}$ channels in the secretion mechanism.

Second, we assessed participation of SNAP25, a synaptic vesicle protein that is a component of the SNARE (SNAP receptor) complex (Damer and Creutz, 1994; Rothman, 1994; Scheller, 1995; Südhof, 1995). Botulinum toxin cleaves SNAP25 and interferes with microvesicle docking and fusion during the exocytotic process (Yamada et al., 1996b; Yatsushiro et al., 1997). Indeed, immunoblot analysis using SNAP25 antibodies shows that BoNT/E treatment of pinealocytes resulted in cleaved SNAP25 without affecting VAMP2 (Fig. 3, top panel). Significantly, BoNT/E treatment also resulted in inhibited acetylcholine- 
A

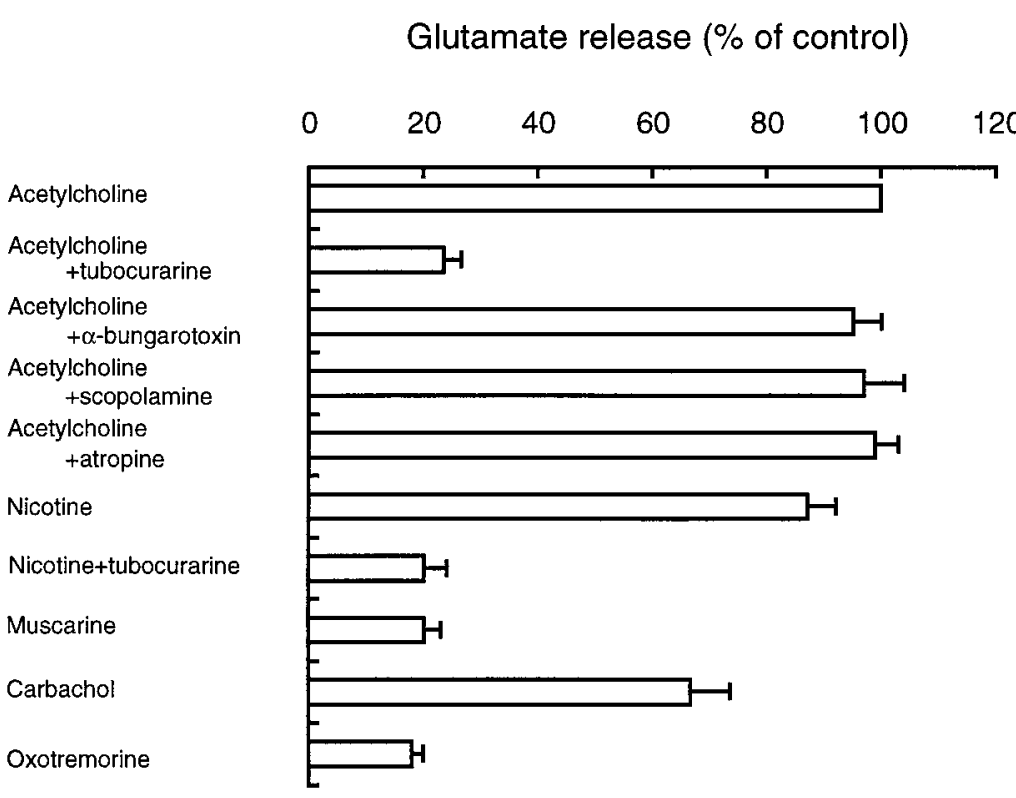

B

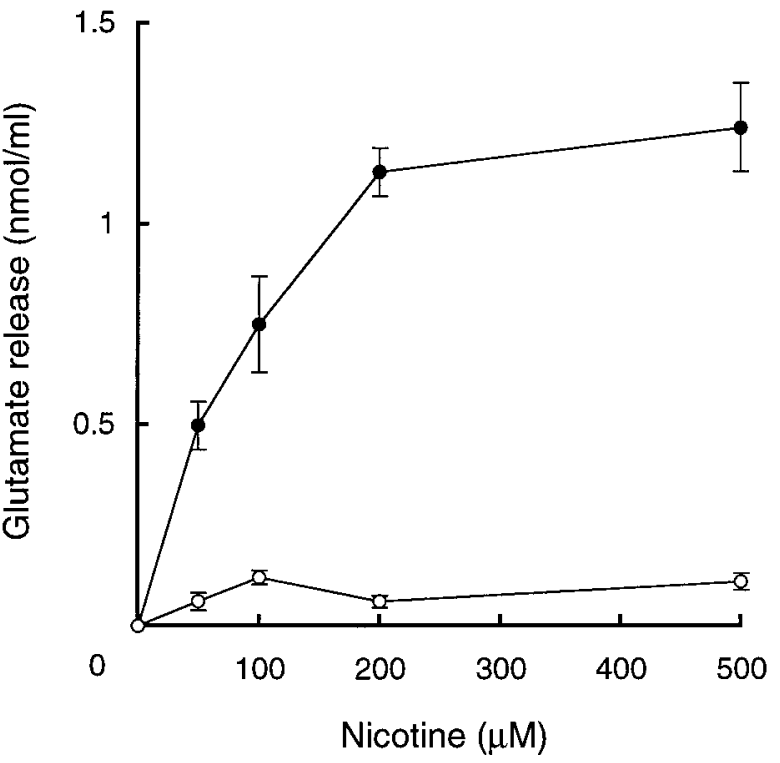

Figure 4. Pharmacological $(A)$ and nicotine $(\bullet)$ and muscarine $(\bigcirc)$ dose-dependent $(B)$ effects on glutamate secretion in the presence or absence of acetylcholine receptor antagonists at 10 min were determined as described in the legend of Figure 1 . Results are expressed as relative values $(A)$ or means $(B) \pm$ SEM (4 independent experiments); $100 \%$ activity is $1.7 \mathrm{nmol}$ glutamate $/ 10^{6}$ cells. Reagents at the following concentrations were used: acetylcholine and receptor agonists, $200 \mu \mathrm{M}$; tubocurarine, scopolamine and atropine, $400 \mu \mathrm{M}$; and $\alpha$-bungarotoxin, $100 \mathrm{nM}$.

Glutamate release (\% of control)

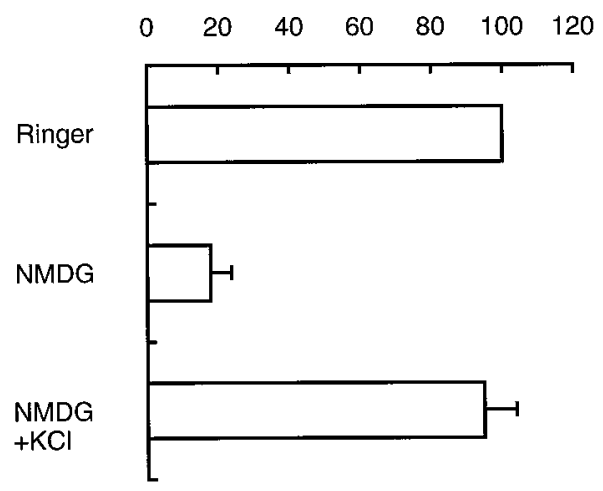

Figure 5. $\mathrm{Na}^{+}$requirement for acetylcholine-evoked glutamate secretion. Cells were incubated in Ringer's solution (Ringer) or Ringer's solution containing NMDG (NMDG). The acetylcholine-evoked glutamate released at $10 \mathrm{~min}$ was determined. In $N M D G+\mathrm{KCl}, 50 \mathrm{~mm} \mathrm{KCl}$ was added in Ringer's solution containing NMDG to initiate glutamate secretion. Results are expressed as relative values \pm SEM (4 independent experiments); $100 \%$ activity is $1.8 \mathrm{nmol}$ glutamate $/ 10^{6}$ cells.

evoked glutamate secretion in a toxin concentration-dependent manner (Fig. 3). Together with the results indicating the role of $\mathrm{Ca}^{2+}$, these results are fully consistent with the properties of microvesicle exocytosis (Yamada et al., 1996a,b) and strongly suggest that acetylcholine triggers glutamate secretion through this process.

\section{Involvement of $\mathbf{n A c h R}$ in glutamate secretion}

Acetylcholine binds to both nicotinic and muscarinic acetylcholine receptors. To determine which type of receptor is involved in pinealocyte glutamate secretion, pharmacological analysis was conducted. As shown in Figure $4 A$, glutamate secretion was triggered by the addition of nicotine but not muscarine: the $K_{\mathrm{m}}$ and $V_{\max }$ values for nicotine were $77 \mu \mathrm{M}$ and $0.21 \mathrm{nmol} / \mathrm{min}$ per $10^{6}$ cells, respectively (Fig. $4 B$ ). Both nicotine- and acetylcholineevoked glutamate secretion were inhibited $80 \%$ by the addition of tubocurarine, a competitive inhibitor of the nAchR, whereas scopolamine and atropine, antagonists of the muscarinic receptor (Pujito et al., 1991b), or $\alpha$-bungarotoxin, a selective inhibitor for some subtypes of nAchRs, were ineffective (Fig. 4A). Carbachol at $0.2 \mathrm{~mm}$, an agonist for both muscarinic and nicotinic receptors (Pujito et al., 1991b), stimulated secretion. Neither scopolamine nor atropine at $400 \mu \mathrm{M}$ affected the carbachol-induced glutamate secretion (data not shown). These results specify that an $\alpha$-bungarotoxin-insensitive $\mathrm{nAchR}$ is responsible for glutamate secretion.

The requirement for extracellular $\mathrm{Na}^{+}$will also distinguish nicotinic and muscarinic receptors. Replacement of $\mathrm{Na}^{+}$with the nonpermeating cation $N$-methyl-D-glucamine (NMDG) (Letz et al., 1997) significantly decreased acetylcholine-evoked glutamate secretion (Fig. 5). The same pinealocytes exhibited normal levels of $\mathrm{KCl}$-evoked glutamate secretion, indicating that the cells retain microvesicle exocytosis capability. Because $\mathrm{Na}^{+}$is required for $\mathrm{nAchR}$ function (see below), these results further supported the involvement of $\mathrm{nAchR}$ but not muscarinic receptor in acetylcholine-evoked glutamate secretion.

\section{Functional coupling between nAchR and L-type $\mathrm{Ca}^{2+}$ channel}

After activation, the nAChR channel increases $\mathrm{Na}^{+}$conductance and depolarizes the pinealocyte membrane (Letz et al., 1997). Depolarization activates L-type $\mathrm{Ca}^{2+}$ channels, and the resultant 
A

Os

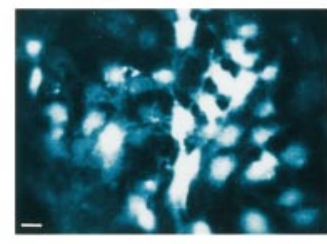

B

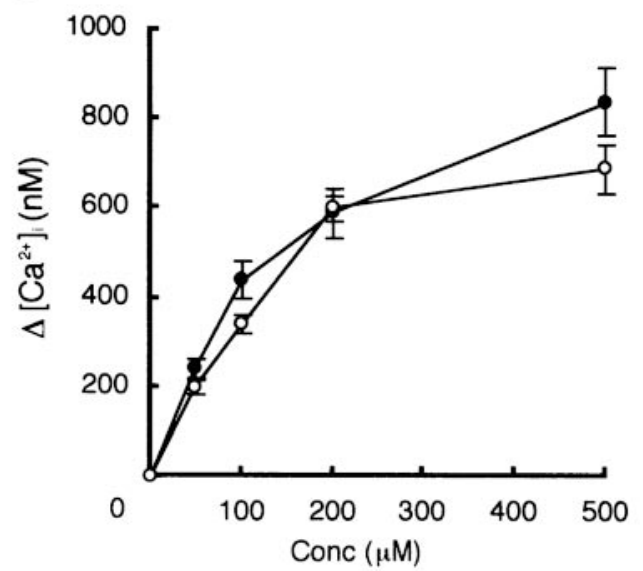

$15 s$
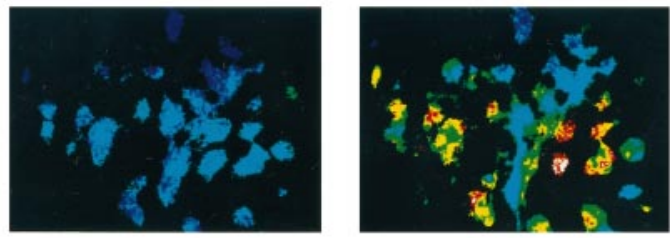

30 s

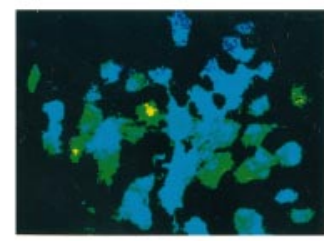

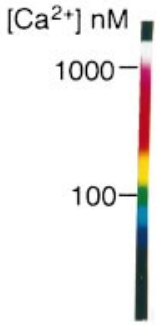

C

\begin{tabular}{lccc}
\hline Agent & $\begin{array}{c}\text { Peak of }\left[\mathrm{Ca}^{2+}\right]_{\mathrm{i}} \\
\mathrm{nM}\end{array}$ & $\begin{array}{c}{\left[\mathrm{Ca}^{2+}\right]_{\mathrm{i}} \text { response }} \\
\%\end{array}$ & $\mathrm{n}$ \\
\hline Acetylcholine $(200 \mu \mathrm{M})$ & $615 \pm 62$ & 81 & 320 \\
Nicotine $(200 \mu \mathrm{M})$ & $603 \pm 38$ & 77 & 136 \\
\hline
\end{tabular}

E
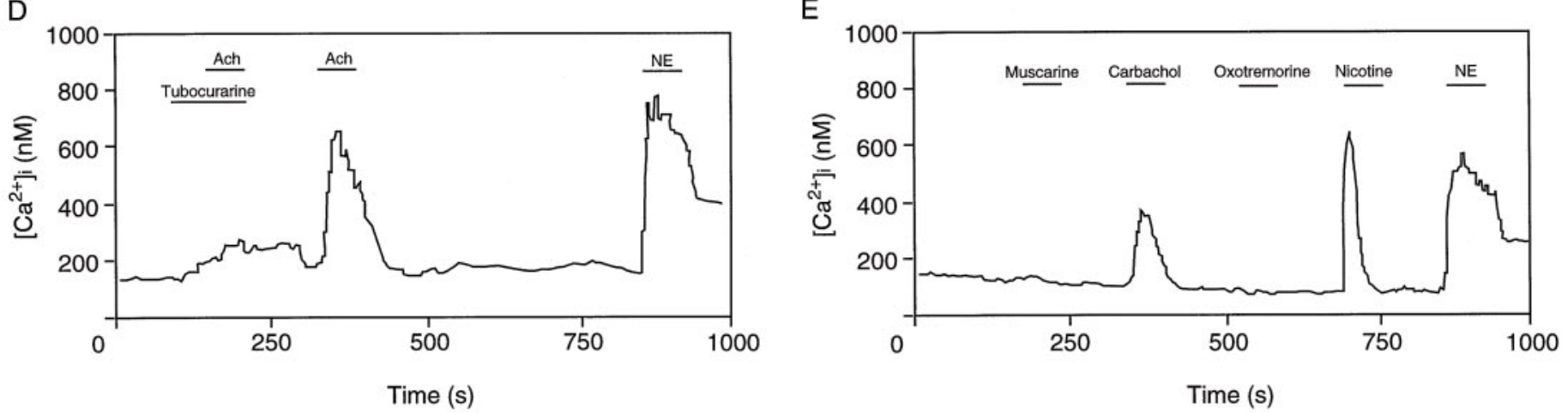

Figure 6. Acetylcholine or nicotine increases intracellular $\left[\mathrm{Ca}^{2+}\right]$ in pinealocytes. $A$, Typical intracellular $\left[\mathrm{Ca}^{2+}\right]$ transients as monitored by fura-2 AM fluorescence. A fluorescence micrograph was shown to indicate fura-2 AM-loaded pinealocytes (left). At 0 time, acetylcholine $(200 \mu \mathrm{M})$ was added and the change in fura-2 AM fluorescence within individual pinealocytes was followed. $B$, Dose dependencies of acetylcholine $(\bullet)$ and nicotine $(\bigcirc)$ are shown. Results are expressed as means of peak values at $\sim 15 \mathrm{sec} \pm$ SEM obtained from 20 cells. $C$, The majority of pinealocytes respond after the addition of acetylcholine or nicotine (200 $\mu \mathrm{M}$ each). $D$, E. Traces of fura-2 AM fluorescence indicating intracellular [Ca $\left.{ }^{2+}\right]$ transients from a single pinealocyte. The following compounds were added as indicated by the bars: $200 \mu \mathrm{M}$ acetylcholine, $200 \mu \mathrm{M}$ nicotine, $1 \mu \mathrm{M}$ NE, $400 \mu \mathrm{M}$ tubocurarine, 200 $\mu \mathrm{M}$ muscarine, $200 \mu \mathrm{M}$ carbachol, or $200 \mu \mathrm{M}$ oxotremorine.

increase of intracellular $\left[\mathrm{Ca}^{2+}\right]$ should trigger microvesicle exocytosis. To demonstrate that the above cascade is operating in our experimental conditions, we observed acetylcholine- or nicotineevoked intracellular $\left[\mathrm{Ca}^{2+}\right]$ transients in fura-2 AM-loaded pinealocytes in the presence or absence of various channel blockers. Either acetylcholine or nicotine evoked increased intracellular $\left[\mathrm{Ca}^{2+}\right]$ in pinealocytes in a dose-dependent manner (Fig. 6A-C). Apparent $K_{\mathrm{m}}$ values for acetylcholine and nicotine are 86 and 90 $\mu \mathrm{M}$, respectively (Fig. $6 B$ ). A rise of intracellular $\left[\mathrm{Ca}^{2+}\right]$ required extracellular $\mathrm{Ca}^{2+}$ and was inhibited by L-type $\mathrm{Ca}^{2+}$ channel blockers such as nifedipine (data not shown). Removing $\mathrm{Na}^{+}$ from the medium also blocked the acetylcholine effect (data not shown), as did tubocurarine (Fig. 6D). Although carbachol stimulated increased intracellular $\left[\mathrm{Ca}^{2+}\right]$, no muscarinic acetylcholine receptor agonists caused increased intracellular $\left[\mathrm{Ca}^{2+}\right]$ (Fig.
$6 E$ ). Essentially the same effects on the requirement of extracellular $\mathrm{Na}^{+}$and $\mathrm{Ca}^{2+}$ and on inhibitor sensitivities were observed in the case of nicotine-evoked $\left[\mathrm{Ca}^{2+}\right]$ transients (data not shown). These results were consistent with the previous observations by Letz et al. (1997). We conclude that nAchR and L-type $\mathrm{Ca}^{2+}$ channel are functionally coupled in pinealocytes.

\section{Acetylcholine-evoked inhibition of melatonin synthesis}

We showed previously that L-glutamate secreted from pinealocytes may inhibit NE-dependent melatonin synthesis via the mGluR3-mediated inhibitory cAMP cascade (Yamada et al., 1998). As a final step of the study, we tested whether stimulation of nAchR would result in inhibition of NE-dependent melatonin synthesis as well.

As expected, either acetylcholine or nicotine strongly inhibited 


\begin{tabular}{|c|c|c|}
\hline Additions & $\begin{array}{l}\text { Melatonin production } \\
(\%)\end{array}$ & $\begin{array}{l}\text { NAT } \\
\text { activity }(\%)\end{array}$ \\
\hline \multicolumn{3}{|l|}{ Experiment 1} \\
\hline Control & 100 & 100 \\
\hline \multicolumn{3}{|l|}{ Acetylcholine } \\
\hline $50 \mu \mathrm{M}$ & $60.4 \pm 2.9$ & $65.3 \pm 4.4$ \\
\hline $100 \mu \mathrm{M}$ & $43.3 \pm 3.8$ & $51.3 \pm 3.2$ \\
\hline $200 \mu \mathrm{M}$ & $25.4 \pm 1.8$ & $32.6 \pm 4.9$ \\
\hline $500 \mu \mathrm{M}$ & $27.4 \pm 0.9$ & $32.7 \pm 2.5$ \\
\hline Acetylcholine + tubocurarine & $86.3 \pm 6.3$ & $84.0 \pm 7.9$ \\
\hline Acetylcholine + MCCG & $58.9 \pm 8.3$ & $79.0 \pm 6.9$ \\
\hline \multicolumn{3}{|l|}{ Experiment 2} \\
\hline Control & 100 & 100 \\
\hline \multicolumn{3}{|l|}{ Nicotine } \\
\hline $50 \mu \mathrm{M}$ & $53.2 \pm 7.6$ & $61.5 \pm 5.8$ \\
\hline $100 \mu \mathrm{M}$ & $40.1 \pm 4.9$ & $43.1 \pm 6.2$ \\
\hline $200 \mu \mathrm{M}$ & $26.3 \pm 5.9$ & $24.1 \pm 2.9$ \\
\hline $500 \mu \mathrm{M}$ & $28.4 \pm 1.3$ & $31.0 \pm 2.7$ \\
\hline Muscarine & $76.3 \pm 3.2$ & $82.7 \pm 2.4$ \\
\hline Carbachol & $53.4 \pm 2.9$ & $44.9 \pm 4.2$ \\
\hline Oxotremorine & $73.0 \pm 5.2$ & $70.6 \pm 3.8$ \\
\hline Nicotine + tubocurarine & $79.4 \pm 8.3$ & $65.8 \pm 4.8$ \\
\hline Nicotine + MCCG & $72.8 \pm 6.4$ & $60.7 \pm 6.4$ \\
\hline
\end{tabular}

Pineal glands ( 3 glands per experiment) were incubated in $1 \mathrm{ml}$ of DMEM for $1 \mathrm{hr}$. After glands were washed with DMEM, $10 \mu \mathrm{M} \mathrm{NE}$ (experiments 1 and 2) plus the indicated compound (200 $\mu \mathrm{M}$ each, unless stated otherwise) were added. In some cases, organs were preincubated with $2 \mathrm{~mm}$ MCCG or $400 \mu \mathrm{M}$ tubocurarine for 30 $\mathrm{min}$, and then the indicated compounds were added. After further incubation for 6 $\mathrm{hr}$, the medium was collected and melatonin content was determined. Simultaneously, glands were homogenized and NAT activity was assayed. The results are presented as relative activity \pm SEM (4 independent experiments) with $100 \%$ activity of 0.60 and $0.65 \mathrm{nmol} / \mathrm{ml}$ of melatonin synthesis, and 2.4 and $2.1 \mathrm{nmol}$. $\min ^{-1} \cdot \mathrm{mg}^{-1}$ protein of NAT activity in experiments 1 and 2, respectively. Neither acetylcholine nor AchR agonists affected the level of these activities in the absence of NE. In experiment 1, $50 \mu \mathrm{M}$ eserine was also included in the assay medium.

NE-dependent melatonin synthesis with $50 \%$ inhibition attained at 75 and $60 \mu \mathrm{M}$, respectively (Table 1). Muscarine at $0.2 \mathrm{~mm}$ had only a slight effect. The nicotine-evoked inhibition was prevented by the treatment of $0.4 \mathrm{~mm}$ tubocurarine. Consistent with the glutaminergic signaling cascade, either acetylcholine or nicotine also inhibited NE-dependent NAT activity (Table 1). Inhibition of melatonin synthesis and NAT activity were recovered to control levels after treatment with $2 \mathrm{mM}$ dibutylyl cAMP, a nonhydrolyzable cAMP analog (data not shown). Furthermore, the acetylcholine- or nicotine-evoked inhibition was blocked when pineal glands were treated with MCCG, a specific antagonist of class II mGluR. This compound also blocked glutamate action in the pineal gland (Yamada et al., 1998) (Table 1). These results clearly showed that the class II mGluR-mediated inhibitory cAMP cascade is involved in acetylcholine-evoked inhibition of melatonin synthesis.

\section{DISCUSSION}

In this study, we report that acetylcholine triggers glutamate exocytosis from rat pinealocytes by way of $\mathrm{nAchR}$ and L-type $\mathrm{Ca}^{2+}$ channels. The data presented here and in previous reports are consistent with the following signaling cascade: activation of $\mathrm{nAchR}$ depolarizes the pinealocyte membrane by increasing $\mathrm{Na}^{+}$ conductance. Depolarization activates L-type $\mathrm{Ca}^{2+}$ channels resulting in increased intracellular $\left[\mathrm{Ca}^{2+}\right]$, which in turn triggers microvesicle exocytosis. Secreted glutamate activates mGluR3 receptors leading to inhibited NE-dependent melatonin synthesis (Yamada et al., 1998). Although the physiological significance of $\mathrm{nAchR}$ has yet to be established, the results reported here clearly indicate functional coupling between $\mathrm{nAchR}$ and L-type $\mathrm{Ca}^{2+}$ channels and participation in the glutaminergic inhibitory mechanism of melatonin synthesis in pineal glands.

To our knowledge, this is the first example of $\mathrm{nAchR}$ regulation of glutamate secretion in endocrine cells. Enhancement of neurotransmitter release on stimulation of $\mathrm{nAchR}$ has been observed in various neurons. nAchRs are classified into two categories based on sensitivity to nicotine and $\alpha$-bungarotoxin (for review, see Role and Berg, 1996). One class requires relatively high concentrations of nicotine $(\sim 100 \mu \mathrm{M})$ for activation and is insensitive to $\alpha$-bungarotoxin, whereas the other type activates at low nicotine concentrations $(<1 \mu \mathrm{M})$ and is sensitive to $\alpha$-bungarotoxin. Glutamate secretion in pinealocytes seems to be of the former type, because a high concentration of nicotine was required for activation and the receptor was insensitive to $\alpha$-bungarotoxin (Fig. 4). This is consistent with in situ hybridization studies reporting the presence of $\alpha$-bungarotoxin-insensitive $\alpha 3 \beta 2$ subunits in the pineal gland (Wada et al., 1989).

Recently, Pujito et al. (1991b) and Drijfhout et al. (1996) reported that muscarinic receptor agonists strongly inhibited melatonin synthesis in rat pineal gland; however, such inhibition was not observed in our hands (Table 1). Muscarinic receptor agonists appear to target presynaptic membranes and block NE release from sympathetic neurons. This effect causes decreased melatonin output (Drijf hout et al., 1996). Such muscarinic agonist action would not be observed in our assay conditions because exogenous $\mathrm{NE}$ was included to ensure full melatonin output. It is reasonable that acetylcholine has alternative pathways to inhibit $\mathrm{NE}$ dependent melatonin synthesis. One pathway involves presynaptic modulation of $\mathrm{NE}$ release through muscarinic acetylcholine receptors (Drijfhout et al., 1996) and the other involves nAchRmediated glutamate-evoked inhibitory cascade as shown here in pinealocytes.

We showed that cholinergic and glutaminergic signaling pathways overlap on the way to the end point of decreased melatonin output. Our conclusion immediately raises the fascinating hypothesis that the CNS is responsible for negative regulation of melatonin synthesis. Either parasympathetic neurons innervating the gland or cholinergic interneurons present in the gland (Pujito et al., 1991a; Wessler et al., 1997) may participate in regulation of the melatonin synthesis. Clearly, more extensive studies are necessary.

In summary, we presented evidence that acetylcholine initiates an intrinsic glutaminergic system via $\mathrm{nAch}$ to inhibit melatonin synthesis in pineal glands. This finding may define the major physiological role of nicotinic acetylcholine receptors in the endocrine system.

\section{REFERENCES}

Axelrod J (1974) The pineal gland: a neurochemical transducer. Science 184:1341-1348.

Bellemann P, Frankowiak G (1985) Different receptor affinities of enantiomers of Bay K 8644, a dihydropyridine calcium channel activator. Eur J Pharmacol 118:187-194.

Damer CK, Creutz CE (1994) Secretory and synaptic vesicle membrane proteins and their possible roles in regulated exocytosis. Prog Neurobiol 43:511-536.

Drijfhout WJ, Grol CJ, Westerink BHC (1996) Parasympathetic inhibition of pineal indole metabolism by prejunctional modulation of noradrenaline release. Eur J Pharmacol 308:117-124. 
Foulkes NS, Borjigin J, Snyder SH, Sassone-Corsi P (1997) Rhythmic transcription: the molecular basis of circadian melatonin synthesis. Trends Neurosci 20:487-492.

Godel H, Graser T, Foeldi P, Fuerst P (1984) Measurements of free amino acids in human biological fluids by high-performance liquid chromatography. J Chromatogr 297:49-61.

Klein DC (1985) Photoneural regulation of the mammalian pineal gland (Ciba Foundation Symposium 117): Photoperiodism, melatonin, and the pineal gland (Evered D, and Clark S, eds), pp 38-56. London: Pitman.

Korf H-W, Schomerus C, Maronde E, Stehle JH (1996) Signal transduction molecules in the rat pineal organ: $\mathrm{Ca}^{2+}$, pCREB, and ICER. Naturwissenshaften 83:535-543.

Laitinen JT, Laitinen KSM, Kokkola T (1995) Cholinergic signaling in the rat pineal gland. Cell Mol Neurobiol 15:177-192.

Letz B, Schomerus C, Maronde E, Korf H-W, Korbmacher C (1997) Stimulation of a nicotinic ACh receptor causes depolarization and activation of L-type $\mathrm{Ca}^{2+}$ channels in rat pinealocytes. J Physiol (Lond) 499:320-340.

Moller M (1992) Fine structure of pinealopetal innervation of the pineal gland. Microsc Res Tech 21:188-204.

Moriyama Y, Yamamoto A (1995a) Microvesicles isolated from bovine pineal gland specifically accumulate $L$-glutamate. FEBS Lett 367:233-236.

Moriyama Y, Yamamoto A (1995b) Vesicular $L$-glutamate transporter in microvesicles from bovine pineal glands. J Biol Chem 270:22314-22320.

Moriyama Y, Yamamoto A, Yamada H, Tashiro Y, Futai M (1996) Role of endocrine cell microvesicles in intercellular chemical transduction. Biol Chem 377:155-165.

Nowycky MC, Fox AP, Tsien RW (1985) Three types of neuronal calcium channel with different calcium agonist sensitivity. Nature 316:440-449.

Ogura A, Myojo Y, Higashida H (1990) Bradykinin-evoked acetylcholine release via inositol triphosphate-dependent elevation in free calcium in neuroblastoma $\mathrm{x}$ glioma hybrid NG108-15 cells. J Biol Chem 265:3577-3584.

Pujito PP, Mikkelsen JD, Govitrapong P, Moller M (1991a) A cholinergic innervation of the bovine pineal gland visualized by immunohistochemical detection of choline acetyltransferase-immunoreactive nerve fibers. Brain Res 545:49-58.

Pujito PP, Govitrapong P, Ebadi M (1991b) Inhibitory actions of muscarinic cholinergic receptor agonists on serotonin $\mathrm{N}$-acetyltransferase in bovine pineal explants in culture. Neurochem Res 16:885-889.

Reiter J (1991) Pineal gland: interaction between the photoperiodic environment and the endocrine system. Trends Endocrinol Metab 13-19.

Reuss S, Schroder B, Schroder H, Maelicke A (1992) Nicotinic cholinoceptors in the rat pineal gland as analyzed by western blot, light- and electron microscopy. Brain Res 573:114-118.

Role LW, Berg DK (1996) Nicotinic receptors in the development and modulation of CNS synapses. Neuron 16:1077-1085.
Rothman JE (1994) Mechanism of intracellular protein transport. Nature 372:55-63.

Sagara Y, Okatani Y, Yamanaka S, Kiriyama T (1988) Determination of plasma 5-hydroxytryptophan, 5-hydroxytryptamine, 5-hydroxyindoleacetic acid, tryptophan, and melatonin by HPLC with electrochemical detection. J Chromatogr 431:170-176.

Scheller RH (1995) Membrane trafficking in the presynaptic nerve terminal. Neuron 14:893-897.

Sekiyama N, Hayashi Y, Nakanishi S, Jane DE, Tse H-W, Birse EF, Watkins JC (1996) Structure-activity relationship of new agonists and antagonists of different metabotropic glutamate receptor subtypes. Br J Pharmacol 117:1493-1503.

Stankov B, Cimino M, Marini P, Lucini V, Fraschini F, Clementi F (1993) Identification and functional significance of nicotinic cholinergic receptors in the rat pineal gland. Neurosci Lett 156:131-134.

Südhof TC (1995) The synaptic vesicle cycle: a cascade of proteinprotein interactions. Nature 375:645-653.

Thomas KB, Zawilska J, Iuvone PM (1990) Arylalkylamine (serotonin) $N$-acetyltransferase assay using high-performance liquid chromatography with fluorescence or electrochemical detection of $\mathrm{N}$ acetyltryptamine. Anal Biochem 184:228-234.

Tsien RW, Lipscombe D, Madison DV, Bley KR, Fox AP (1988) Multiple types of neuronal calcium channels and their selective modulation. Trends Neurosci 11:431-438.

Wada E, Wada K, Boulter J, Deneris E, Heinemann S, Patrick J, Swanson LW (1989) Distribution of alpha2, alpha3, alpha4, and beta2 neuronal nicotinic receptor subunit mRNAs in the central nervous system: a hybridization histochemical study in the rat. J Comp Neurol 284:314-335.

Wessler I, Reinheimer T, Bittinger F, Kirkpatrick CJ, Schenda J, Vollath L (1997) Day-night rhythm of acetylcholine in the rat pineal gland. Neurosci Lett 224:173-176.

Yamada H, Yamamoto A, Yodozawa S, Kozaki S, Takahashi M, Michibata H, Morita M, Furuichi T, Mikoshiba K, Moriyama Y (1996a) Microvesicle-mediated exocytosis of glutamate is a novel paracrine-like chemical transduction mechanism and inhibits melatonin secretion in rat pinealocytes. J Pineal Res 21:175-191.

Yamada $\mathrm{H}$, Yamamoto A, Takahashi $M$, Michibata $H$, Kumon $H$, Moriyama Y (1996b) The L-type $\mathrm{Ca}^{2+}$ channel is involved in microvesicle-mediated glutamate exocytosis from rat pinealocytes. $\mathrm{J}$ Pineal Res 21:165-174.

Yamada H, Yastushiro S, Ishio S, Hayashi M, Nishi T, Yamamoto A, Futai M, Yamaguchi A, Moriyama Y (1998) Metabotropic glutamate receptors negatively regulate melatonin synthesis in rat pinealocytes. J Neurosci 18:2056-2062.

Yatsushiro S, Yamada H, Kozaki S, Kumon H, Michibata H, Yamamoto A, Moriyama Y (1997) L-Aspartate but not the D form is secreted through microvesicle-mediated exocytosis and is sequestered through $\mathrm{Na}^{+}$-dependent transporter in rat pinealocytes. J Neurochem 69: $340-347$. 